UDC 811.111: 81'42

DOI https://doi.org/10.24919/2308-4863/41-3-18

Ivan SEMENIST, orcid.org/0000-0002-0847-8856 Candidate of Historical Sciences, Head of Oriental Languages and Translation Department Borys Grinchenko Kyiv University (Kyiv,Ukraine)i.semenist@kubg.edu.ua

Rusudan MAKHACHASHVILI, orcid.org/0000-0002-4806-6434 Habilitated Doctor, Associate Professor, Head of Romance Languages and Typology Department Borys Grinchenko Kyiv University (Kyiv, Ukraine) r.makhachashvili@kubg.edu.ua

\title{
INNOVATIVE EDUCATIONAL COMMUNICATION IN THE DIGITAL DISCOURSE: MODELS AND TOOLS
}

The paper main focus is the inquiry into the models and tools of comprehensive structuring of the innovative educational communication in the digital discourse (innovative educational communication in the digital ambient as construed by the transformative innovative strata and communicative application, facilitated by the modern European and Oriental languages of international communication - English, Spanish, French, Chinese, Japanese, accordingly). The problem of theoretical and methodological substantiation of cross-cutting principles, directions, mechanisms, and results of qualitative modeling of macro- and microstructures of verbal means and processing tools in the realm of digital educational communication, as a consolidated linguistic object, is investigated in depth. Mosaic, simulation, multidimensional, and framework approaches to understanding complex dynamic linguistic phenomena and entities, prioritized by this methodological context, allowed us to identify the ontological nature of educational communication units of the globalized languages in the sphere of innovative educational communication. The ICT, e-learning, hybrid learning, digital competencies thesaurus, that facilitates innovative educational communication, is structured to define and categorize the key components of innovative cyberterminology, instrumental to e-learning environment construction and functioning. Suggested are the innovative educational communication macro-, micro- and supra-structures modeling and digital processing based on three groundwork principles: 1) Intranet educational anthroposphere (the anthropic environment within World Wide Web); 2) Outernet educational anthroposphere (e-reality components, functions outside the realm of World Wide Web); 3) Technogenic educational anthroposphere (transoriented anthropic environment components with an anthropic-for-congenerous substituted ontological parameter).

The dynamic interaction of the structural tiers of the ICTs content plane within the strata of innovative educational communication is characterized by the anthropogenic and cognitive parameters of the content plane, mediated by the subjective and collective cognitive experience of digital education stakeholders, embodied in the framework digital transformation of innovative communicative educational scenarios.

Key words: innovative educational communication, framework transformation, ICT, e-learning, hybrid learning, digital competences thesaurus, modelling, phenomenological marker.

Іван СЕМЕНICT, orcid.org/0000-0002-0847-8856 кандидат історичних наук, завідувач кафедри східних мов та перекладу Київского університету імені Бориса Грінченка

(Київ, Україна) i.semenist@kubg.edu.иа

Русудан МАХАЧАШВІЛІ, orcid.org/0000-0002-4806-6434 доктор філологічних наук, дочент, завідувач кафедри романської філологї та порівняльно-типологічного мовознавства Київского університету імені Бориса Грінченка (Київ, Україна) r.makhachashvili@kubg.edu.ua 


\section{ІННОВАЦІЙНА ОСВІТНЯ КОМУНІКАЦІЯ У ЦИФРОВОМУ ДИСКУРСІ: МОДЕЛІ ТА ІНСТРУМЕНТИ}

Основна увага в роботі зосереджена на дослідженні моделей та інструментів всебічного структурування інноваційної освітньої комунікації в циирровому дискурсі (інноваційна освітня комунікація в ичифровому середовищзі у розумінні трансформаційних інноваційних шарів та комунікативного застосування, опосередковані сучасними європейськими та східнми мовами міжнародного спілкування - англійська, іспанська, франиузька, китайська, японська, відповідно). Проблема теоретичного та методологічного обтрунтування наскрізних принципів, напрямів, механізмів та результатів якісного моделювання макро- та мікроструктур вербальних засобів та засобів обробки у сфері ичифрового освітнього спілкування, як консолідованого мовного об'єкта, досліджується грунтовно. Мозаїчний, імітачійний, багатовимірний та рамковий підходи до розуміння складних динамічних лінгвістичних явищ та сутностей, пріоритетні для изього методологічного контексту, дозволили нам виявити онтологічну природу навчальних комунікаційних одиниць глобалізованих мов у сфері інноваційного освітнього спілкування. Тезаурус IKT, електронного навчання, гібридного навчання, циифрових компетенцій, щцо сприяє інноваційному освітньому спілкуванню, побудований для визначення та категоризації ключових компонентів інноваиійної кібертермінології, щзо сприяють побудові та функціонуванню середовища електронного навчання. Запропоновано моделювання макро-, мікро- та надструктур інноваційної освітньої комунікації та їх циифрову обробку на основі трьох основних принциипів: 1) Інтранет-освітня антропосфера (антропне середовище у Всесвітній павутині); 2) Зовнішньо-мережева антропосфера освіти (компоненти електронної реальності, функціонують поза сферою Всесвітньої павутини); 3) Техногенна освітня антропосфера (переорієнтовані компоненти антропогенного середовища з заміщеним онтологічним параметром на однорідний антропний).

Динамічна взаємодія структурних рівнів змістовного рівня IКТ у шарах інноваційної освітньої комунікаціі характеризується антропогенними та когнітивними параметрами змістовної площини, опосередкованими суб' 'кттивним та колективним когнітивним досвідом стейкхолдерів цุифрової освіти, втіленого в рамках ичифрової трансформація інновачійних комунікативних освітніх сиенаріїв.

Ключові слова: інновачійна освітня комунікація, IКТ, фреймова трансформачія, ичифрова освіта, гібридне навчання, циифровий тезаурус компетентностей, моделювання, феноменологічний маркер.

Introduction and state-of-the-art overview. At the turn of the XX - XXI centuries, science acquires the status of extremely effective and dynamic tools of human activity, which determines the interest of scientists in pragmatic aspects and problems of cognitive theory to increase the effectiveness of scientific work by traditional classical means and innovative systems of artificial intelligence (Davis, 2001; Gelenter, 1998; Будкоб 1990).

The network of research space of modern linguistic explorations provides an opportunity to determine the problems of language coding, transcription and mapping of different spheres of actual and conditional reality in linguocognitive (Lakoff, 1987; Langacker, 1991; Селіванова, 2007), linguistic and cultural (Андрейчук, 2011; Маслова, 2007), discursive-communicative (Потапенко, 2011; Морозова, 2004), synergetic (Снікєєва, 2011), activity (Heeter 1989; Heim, 1994) planes.

As an integral product of civilization, modern computer reality has become an independent being. Within it, electronic media act not only as a means of transmitting information or interaction, but also reveal their own world-creating, meaning-making, and, as a consequence, language-forming potential (Hausser, 1999; Makhachashvili, 2020; Борчиков, 2000). Computer being (CB - a term after V. Kutyriev (Кутырьев, 2001) is defined as a complex, multidimensional sphere of synthesis of reality, human experience, and activity, mediated by the latest digital and information technologies; it is the object of study of a wide range of humanities.

In philosophy, computer being is interpreted as a special type of substance - material and ideal reality in the aggregate of all forms of its development (Nyce, 1994; Бабушкін, 1985; Девтерев, 2000); in anthropology - as an environment for the implementation of "post-humanistic" tendencies of anthropogenesis (Hamilton, 1993; Heim, 1994; Мартинюк, 2001); in psychology - as a psychosomatic and emotional plane (Suler, 2009; Баксанский, 2004); in culturology - as a sphere of spiritual experience (Monnin, 2010; Knight, 1994), in sociology - as a system of multilevel, multidirectional social relations (Bell, 1987; Johnson, 2003).

The linguistic aspect of the study of computer being at the turn of the century is determined by objective historical and geopolitical preconditions: cyberization, globalization, informatization of world society, Americanization of world culture, due to which modern English, mostly its American variety, is a priority linguistic and communicative environment of the primary language coding of elements of computer being and its mapping (Makhachashvili \& Swemenist, 2020), exported to globalized languages across the world.

The problem of theoretical and methodological substantiation of cross-cutting principles, directions, 
mechanisms and results of qualitative dynamics of linguistic macro- and microstructures of vocabulary in the realm of computer being, as a consolidated linguistic object, is still waiting to be studied. Consideration of this issue requires the involvement of the phenomenological perspective of the study of complex linguistic objects, given the definition of the main task of phenomenological epistemology - knowledge of the full system of facts of consciousness (Мамардашвили, 1999), constituting the objective world (Zahavi, 2003; Гуссерль, 2001; Будко, 1990).

Objective. The paper overall objective is the inquiry into the models and tools of comprehensive structuring of the innovative educational communication in the digital discourse (generally understood as educational commuication in the digital ambient as construed by the transformative innivative (neological) strata of modern European and Oriental languages of international communication - English, Spanish, French, Chinese, Japanese, accordingly, and facilitated by innovative digital media and communicative formats).

Main findings. The linguistic adaptation of the phenomenological approach to the theoretical and methodological understanding of the dynamics of the vocabulary of modern European and Oriental languages in computer life is based on the concept of the logosphere, synthetically understood as: 1) elements of different spheres of life (Лосев, 1993); 2) the zone of integration of thought-speech continuums (linguo) of cultures (Барт, 1989; Бахтин, 1979).

The turn of the XX-XXI centuries is determined by a significant acceleration of the enrichment of the vocabulary of modern natural languages (Makhachashvili, 2020; Снікєєва, 2011; Шепель, 2010), which determines the need for holistic linguistic research of innovative industries.

Such a study of the vocabulary replenishment of modern European and Oriental languages corresponds to a new integrative direction - phenomenological neolinguistics. The global innovative logosphere of computer being, a component of the international language logosphere, is considered as a plurality of verbal innovations, which are phenomenological correlates of the elements of computer being. Phenomenological neolinguistics provides the researcher with the innovative logosphere of computer existence with the functional integrative methodology and analysis procedures, the application of which allows comprehensive coverage of the relationship between the principles of ultra-dense verbalization of this dimension of reality and mechanisms of neologization, nomination, language reference.
The proposed linguophenomenological approach to the study of the object of study helps to solve the scientific problem of holistic modeling of processes and results of replenishment of the vocabulary of the highly dynamic system of modern languages in general and its individual areas at the turn of XX-XXI centuries.

The object sphere of phenomenological neolinguistics consists of elements of the logosphere (in particular, the linguistic innovative logosphere of computer existence) in the priority determinative dialectical interaction with the constructs of existence - space, time, substance, phenomenon, essence - corresponding to the object field "ontological neolinguistics"; constructs of knowledge/cognition - episteme, concept, concept - corresponding to the object field "epistemological neolinguistics", and constructs of human consciousness/self-consciousness - identification, identity, individuality - corresponding to the object field "anthropological neolinguistics".

This inquiry is based on the initial position on the phenomenological nature of computer lexical innovations of modern European and Oriental languages (namely, the ability to identify, embody and structure elements of the corresponding sphere of being), which enables and provides complex determinative interaction of different substratum and abstract ) parameters of the global language innovation logosphere of computer existence. In the process of research, the algorithm of ontospheric and anthropospheric paradigmatic systematization of general language innovative computer terms is introduced.

Within the phenomenological approach (E. Husserl, R. Ingarden, M. Mamardashvili, G. Shpet) (Zahavi, 2003; Гуссерль, 2001; Ингарден, 1999; Мамардашвили), 1997; Шпет , 2001) global semiotic integration of macro- and microstructures of the language innovative logosphere of computer existence identified as provided and realized due to the deterministic interaction of multisubstrate (linguistic, spatio-spatial, essential, anthropological and social) parameters of this logosphere, given the significant synchronous density of rates and results of parallel development of verbal, ontological and anthropological planes of computer being. Logocentric perspective on computer verbal innovations of modern globalized languages determines their phenomenological nature through the identification of symbolic (structural-semantic) substrate of these linguistic innovations as an empirical source and result of manifestation of substantive characteristics of reality.

Identified and parameterized in the course of our study is a significant density and, to some extent, redun- 
dancy of innovative verbalization of the conceptual and semantic segment of language in the field of innovative educational communication in the digital discourse is, in our opinion, a specific (by extensional characteristics of newly formed language units) (term according to V. Karasyk (Карасик, 2002: 279) and communicative relevance (in terms of the concept of $\mathrm{Z}$. Popova and I. Sternin (Попова, Стернин, 2007: 275) of this conceptual and semantic segment for the global language community. In this way, the significance of understanding the elements of computer reality for a specific language community can be inductively verified.

In turn, empirically clear and observable situational parallelism of the processes of emergence and development of a wide range of different substrate innovative elements of computer being:

- essential elements (space, time, substance),

- gnoseological elements (information, episteme, etc.), anthropological elements (existential state, type of identity, etc.),

- lingual correlates (language sign, language form, language meaning, language content)

determines the theoretical and methodological relevance of defining the problem of positioning this segment of linguistic reality - the general verbal innovations of the English language to denote elements, objects and phenomena of computer life, as special, specific features, consolidated, consistent and systemic type linguistic embodiment (modeling, pictureing) of reality.

Parameterization principles of a concept of "logos" in the paradigm of the humanities in general, linguophilosophy, and linguistics - in particular, allow to identify the features of innovative educational communication in the digital discourse as a complex object system pertaining the following parameters: Ubiquity (inclusiveness); Onthotcentrizm; Integrativity; Automorphism; Normativity; Lingual substantiality; Phenomenology of thesaurus units; Information-capacity; Referential and semiotic isomorphism of the referent and meaning.

Note that through the fragmented set of qualitative features, logosphere is tangent to the concepts of complex system simulators linguistic-mental outlook, such as:

- Model of the world / world view (inclusive, integrative, self-identity);

- Language picture of the world (phenomenology of linguistic constituents - the ability to summarize and signify objects of reality);

- Noosphere (onthotsentrism, info-capacity);

- Communication/discourse.

For the listed set of features the integral notion of IECDD (innovative educational communication in the digital discourse) stands as a semantic synthesis of these concepts (see Figure 1):

The specific differential features of logosphere as a linguistic-onthological, linguistic-phenomenological object are:

- Normativity - arising from the parametric features of the concept of "logos" - (while maintaining the characteristics of dynamic variation and logosphere);

- Lingual substantivity - phenomenological ("actualization") status of meta-language signs membranes in reality;

- The principle of isomorphism of the signified and meaning.

Modelling of the comprehensive framework of educational activities and experiences transformation into digitally enhanced format is, therefore, possible through an interoperable set of parameters (Figure 2):

- Time

- Space

- Communicative distance

- Dependence on ICT tools and infrastructure

- Level of complexity:

In view of the foregoing, the innovative ICT, e-learning, hybrid learning and digital competences logosphere (ICL) as a verbal premise of innovative educational communication in the digital discourse is defined as:

a) a syncretic, consolidated within its semantic scope, plurality of English verbal units that are the asymptotically (i.e. in unlimited approximation) exhaustive embodiments of substantive and factual elements of modern computer being.

b) as a vertically integrated at the macro and micro levels plurality of ICT, e-learning, hybrid learning, intercultural competences thesaurus, its typological specificity are relatively exhaustive phenomenological correlates multi-substrat elements of computer being.

For deductive and inductive determination of types, volume, qualitative characteristics, and direction of dynamics of the content of units of the microstructure of innovative educational communication in the digital discourse the elements of a method of conceptual analysis (Langacker, 1991; Langacker, 2007) in combination with elements of a method of phenomenological reduction (Гуссерль, 2001; Хайдеггер, 2003) are applied by the end-to-end epistemic deconstruction of the object of analysis (linguistic innovation unit) from the empirical sign substrate, which corresponds to the dialectical concept of "phenomenon", through tiers of the intensional and the extensional of the content plane to the substantive characteristics of the referent, corresponding to the dialectical concept of "essence". 


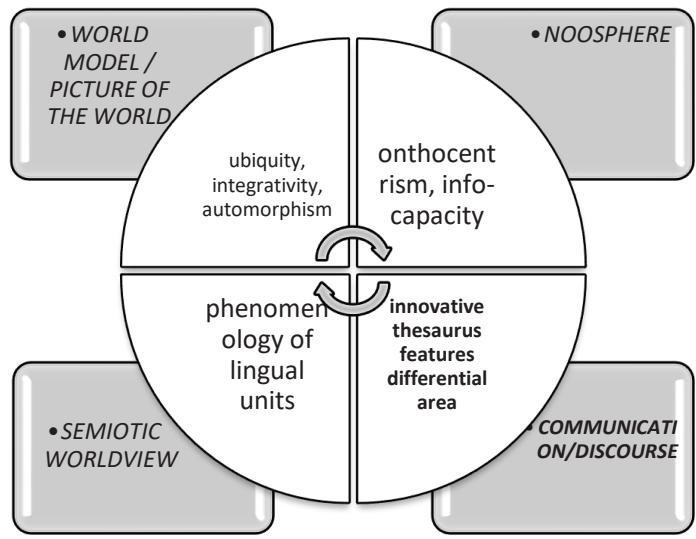

Figure 1. Innovative educational communication in digital discourse model

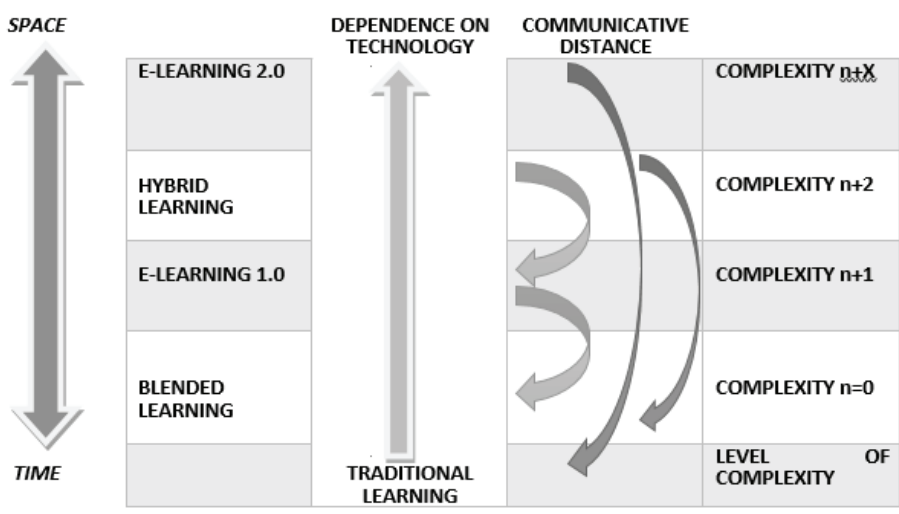

Figure 2. Communiactive Modelling of Innovative Digitally Enhanced Learning Formats

Responsible technology (Dobson, Kürschne, 2021), in this respect, is understood as anthropocentric technology and tools, designed for real-life situations and scenarios, verified by assessment of best practices (James, 2020). The functional interpretation of responsible technology is a best practice application for complex educational communicative scenarios transformation into digital format.

The application of various ICT tools, inherent to each type of innovative communicative educational activity, allows to disclose the transformation procedures of various mandatory educational contexts (for e.g. Final Qualification Assessment) as a complex frame scenario of the dynamic actional or script type, meaning a structure, which presents procedural knowledge about the course of events (Zhabotynska, 2011).

The "frame" is information data, formed in a certain way, that reflects the acquired experience of knowledge about a certain stereotypical situation, which is perceived quite generally, because it can mean action, image, narration etc. (Fillmore, 2010), (Minsky, 1979). Therefore, the framework scenario of Final Qualification Assessment transformation into digital format assisted by ICT tools, comprises of the following separate cognitive schemes:

1) Agency scheme: $X(A G E N T)$ [stakeholder] $\Rightarrow>$ performs EDUCATIONAL ACTIVITY $=>$ [digital equivalent activity]

2) Localization scheme: $X$ (AGENT) [stakeholder $]=>$ performs activity THERE [locus $]=>$ [digital equivalent locus]

3) Instrumental scheme: $X$ (AGENT) [stakeholder] $\Rightarrow>$ uses INSTRUMENT $=>$ for PURPOSE [to perform educational activity] $\Rightarrow>$ [EQUIVALENT ICT TOOLS] for $\Rightarrow$ [DIGITAL EQUIVALENT ACTIVITY]

4) Object scheme: $X$ (INSTRUMENT) [ICT tool] $\Rightarrow$ is APPLIED to PATIENT [educational activity / [digital equivalent activity] $\Rightarrow$ for PURPOSE [educational goal].

Assembled schemes of the Final Qualification Assessment procedure transformation into digital technology assisted format comprise a comprehensive framework, informed by the application of ICT tools and digital communication practices, corresponding to different tiers of educational goals and different interdisciplinary domains (Figure 3): 


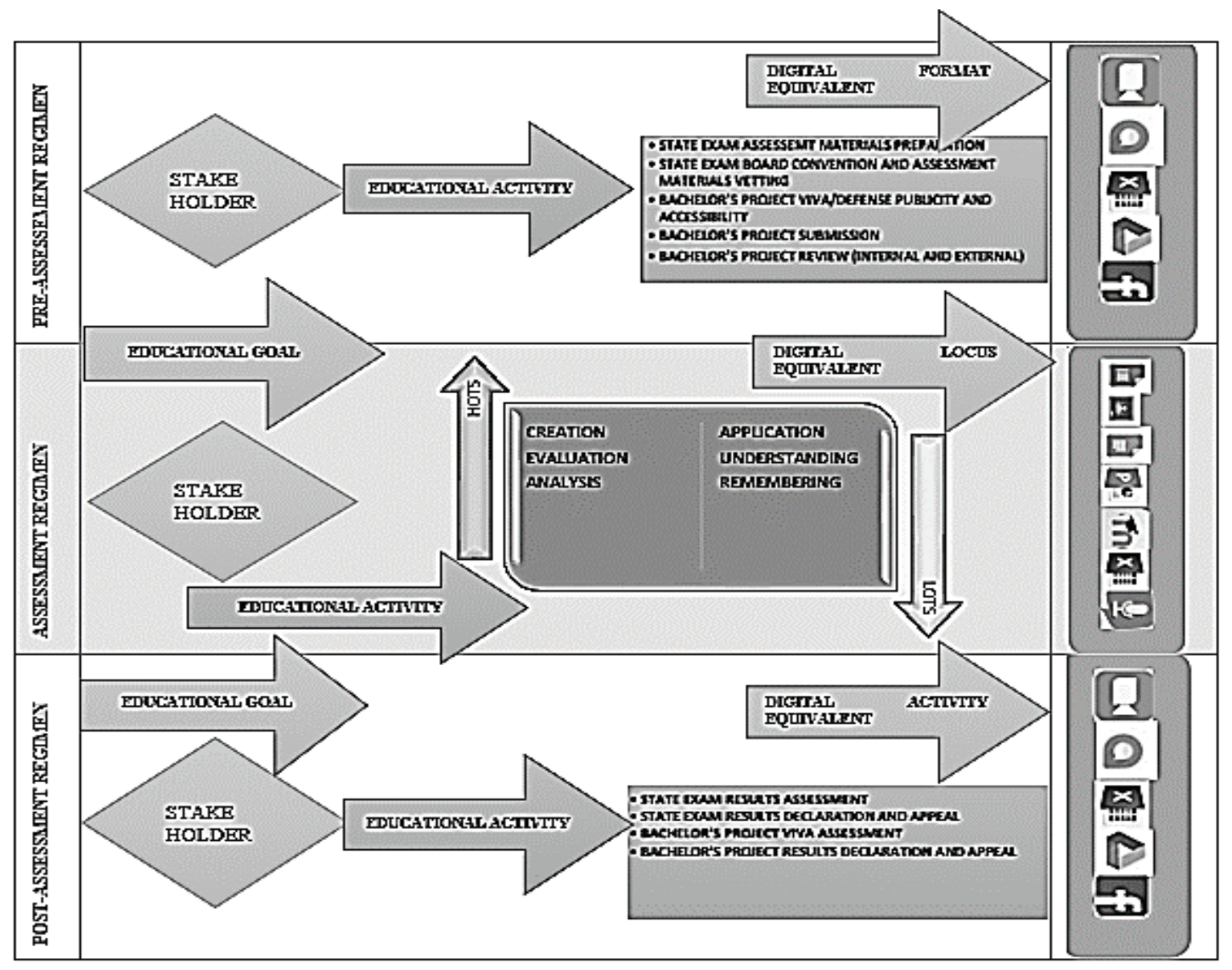

Figure 3. Model of an educational scenario framework transformation into digital format

Qualitative content analysis of the individual communicative and cognitive experiences of stakeholders through hybrid and digital learning was conducted via Voyant Engine (https://voyant-tools.org/) - a family of digital cloud based corpus and text-mining tools. Respondents were, in particular, asked to submit three free ranging concepts each that are individually evocative of hybrid and e-learning through the COVID-19 pandemic timespan. The key concepts, thematically foregrounded in the corpus sample, that designate individual experiences of stakeholders in Oriental and European languages programs of all levels are: TIME; WORK; CONVENIENCE; LACK; SCHEDULE; COMMUNICATION; STRESS.

It bears pointing out that of the thematic concepts foregrounded across the sample by students of Oriental and European languages programs two bear negative connotations - LACK and STRESS. Only the term LACK demonstrates both absolute and relative frequency in the assessment of individual experiences and quality of e-learning and hybrid learning by students of regional universities. The proportionately frequent collocations of the notion LACK in subjective quality assessment of hybrid and digital experiences by stakeholders of Oriental and European languages programs in regional universities of Ukraine are: $\neg$ LACK $\Rightarrow($ of $)=$.> communication; $\neg$ LACK $\Rightarrow(\mathrm{of})=.>$ convenience $\neg$ LACK $=>($ of $)=.>$ digital $/$ online connection $\neg$ LACK $\Rightarrow>($ of $)=$. $>$ resources $\neg$ LACK $=>($ of $)=.>$ teacher/mentor

Content analysis of individual experience and key associations of students of universities on the introduction of hybrid and e-learning in the period COVID-19 revealed the following distribution of key conceptual correlates: TIREDNESS $\Rightarrow$ STRESS $<=$ COMFORT $<=$ TIME $=>$ INCREASE. Content analysis of individual experience and key associations of faculty of universities on the introduction of hybrid and e-learning in the period COVID-19 revealed the following distribution of key conceptual correlates: ABSENCE $\Rightarrow>$ COMMUNICATION $\Rightarrow$ TIREDNESS $<=$ LIVING.

Dynamic interaction of structural level of the content within innovative ICT, e-learning, hybrid learning, digital competences being thesaurus is characterized by the gradual expansion of the onthological referents.

Conclusions. Mosaic, simulation, and multidimensional approaches to understanding complex dynamic linguistic phenomena and entities, prioritized by this methodological context, allowed us to identify the ontological nature of innovative ICT, e-learning, hybrid learning, digital competences thesaurus in innovative educational communication 
(namely, the ability to embody and structure elements of the relevant realm of life independently from the filter of human experience), which enables and provides a complex determinative interaction of multisubstrate (linguistic, existential and anthropological) parameters of the innovative logosphere of computer being.

The dynamic interaction of the structural stages of the innovative ICT, e-learning, hybrid learning, dig- ital competences content plane within the linguistic premises of innovative educational communication is characterized by the expansion of the ontological denotatum, resulting in isolation/absorption/replacement, or partial isolation/absorption/replacement of anthropogenic parameters of the content plane, mediated by the subjective and collective cognitive experience of digital education stakeholders, who are speakers of globalized languages.

\section{BIBLIOGRAPHY}

1. Bell D. Social Framework of the Information Society. Oxford : Oxford U. Press, 1987. 315 p.

2. Davis E. Techgnosis: Myth, Magic and Mysticism in the Age of Information. NY : New York Publishers, Inc., 2001. $377 \mathrm{p}$.

3. Dobson H., Kürschne B. An Introduction to Responsible Technology. Retrieved from: https://tech2impact.com/anintroduction-to-responsible-technology/. 2021.

4. Fillmore, C. J. Frames Approach to Semantic Analysis. In B. Heine, \& H. Narrod (Eds.), The Oxford Handbook of Linguistic Analysis, 2010, pp. 313-340.

5. Gelernter D. Virtual Realism. Oxford : Oxford University Press, 1998.138 p.

6. Hamilton G. Virtual reality. Business Week.1993, Issue 3, pp. 12-22.

7. Hausser R. Foundations of Computational Linguistics. Springer : Verlag Berlin Heidelberg, 1999. 534 p.

8. Heeter $\mathrm{C}$. Implications of new interactive technologies for conceptualizing communication. Media use in the information age. Hillsdale, NJ: Erlbaum, 1989, pp. 85-108.

9. Heim M. Virtual Reality: Practice and Promice. LA : Wesport Publishers, 1994. 233 p.

10. James L. Exploring what "responsible technology" means. Retrieved from: https://medium.com/doteveryone/ exploring-what-responsible-technology-means-4f2a69b50a61. 2020.

11. Johnson F. Shall I Compare Thee to a Swarm of Insects? Searching for the Essence of the World Wide Web. The New York Times. 2003. pp. 10-12.

12. Knight S. Making authentic cultural and linguistic connections. Hispania. 1994, Vol. 77, pp 289-294.

13. Lakoff G. Women, fire and dangerous things. Chicago : CUP, 1987. 614 p.

14. Langacker R. W. Cognitive Grammar. The Oxford Handbook of Cognitive Linguistics. Oxford : Oxford Univ. Press, 2007, pp. 421-462.

15. Langacker R. W. Concept, Image, and Symbol: The Cognitive Basis of Grammar. Berlin \& New York: Mouton de Gruyter, 1991. 395 p.

16. Makhachashvili R., Models and Digital Diagnostics Tools for the Innovative Polylingual Logosphere of Computer Being Dynamics. Italian-Ukrainian Contrastive Studies: Linguistics, Literature, Translation. Monograph. Peter Lang GmbH Internationaler Verlag der Wissenschaften, Berlin, 2020. pp. 99-124.

17. Makhachashvili R., Semenist I. ICT Thesaurus Modelling Recommendations (based on innovations of European and Oriental languages). Studia Filologiczne, 7, 2020, pp. 117-128.

18. Minsky, M. A Framework for Representing Knowledge. In Frame Conceptions and Text Understanding, 1979, pp. $1-25$.

19. Monnin A. Humanity and Digital Characters in Virtual Worlds: Crossing the Fictional Boundaries. Posthumanity : Merger and Embodiment. Oxford, UK : Inter-Disciplinary Press, 2010, pp. 126-131.

20. Nyce J. M. From Memex to Hypertext. NY: Kahn Publications, 1994. 472 p.

21. Searle J. Minds, Brains, and Science. Oxford : Oxford U. Press, 1984. 142p.

22. Suler J. Human Becomes Electric. From Books To Cyberspace Identities. NC : NCU Press, 2009, pp. 21-25.

23. Zhabotynska, S. Lexical Fields and Non-Lineal Dynamics of Cognitive Structures. Visnyk of the Lviv University. Series Philology, 2011, 52, pp. 3-11.

24. Zahavi D. Husserl's Phenomenology. Palo Alto : Stanford University Press, 2003. 312 p.

25. Андреева И. В. Ценностная картина мира как лингвистическая и философская категорія. Аналитика культурологии. 2006, №3, с. 14-21.

26. Андрейчук Н. I. Семіотика лінгвокультурного простору Англії кінця XV - початку XVII століття. Львів: Видавництво Львівської політехніки, 2011. 277 с.

27. Бабушкин В. У. Феноменологическая философия науки - критический анализ. М. : Наука, 1985. 246 с.

28. Баксанский О. Е., Кучер Е. Н. Когнитивное репрезентирование как механизм виртуализации реальности. Вируалистика: экзистенциальные и эпистемологические аспекты. М.: Прогресс-Традиция, 2004. С. $262-285$.

29. Барт Р. Избранные работы: Семиотика: Поэтика. М.: Прогресс, 1989616 с.

30. Бахтин М. М. Эстетика словесного творчества. М.: Искусство, 1979. 424 с.

31. Борчиков С. А. Метафизика виртуальности. Труды лаборатории виртуалистики. 2000. Вып. 8. C. 29-33.

32. Будко В. В. Адекватность научного познания. Харьков: Логос, 1990. 154 с.

33. Гуссерль Э. Картезианские размышления. СПб.: Наука, 2001. 516 с. 
34. Девтерев И. В. Философский анализ феномена интерактивной научной деятельности в INTERNET (феноменологический, эвристический и прагматический аспекты). К., 2000. 188 с.

35. Єнікєєва С. М. Система словотвору сучасної англійської мови: синергетичний аспект (на матеріалі новоутворень кінця XX - початку XXI століть). К., 2011. - 438 с.

36. Ингарден Р. Введение в феноменологию Эдмунда Гуссерля. М.: Дом интеллектуальной книги, 1999. 267 с.

37. Камша В. П., Камша Л. С., Камша Ю. В. Про кібернетику другого етапу НТР. Складні системи $і$ процеси. 2010. 1 (17). C. 25-41.

38. Карасик В. И. Языковой круг: личность, концепты, дискурс. Волгоград: Перемена, 2002. 477 с.

39. Кутырев В. А. Культура и технология: борьба миров. М., Прогресс-Традиция, 2001. 336 с.

40. Лосев А. Ф. Вещь и имя. Бытие. Имя. Космос. М.: Мысль, 1993. С. $805-872$.

41. Мамардашвили М. К., Пятигорский А. М. Символ и сознание. Метафизические рассуждения о сознании, символике и языке. М. : Школа, 1997. 216 с.

42. Мамардашвили М. К. Как я понимаю философию. Избр. ст., докл., высттуп., інтервью. М.: Прогресс, 1999.415 с.

43. Мартинюк А. П. Конструювання гендеру в англомовному дискурсі. Харків: Константа, 2004. 292 с.

44. Мартинюк С. С. Метафізичні виміри людського буття. Запоріжжя: Запорізький державний університет, $2001.198 \mathrm{c}$.

45. Маслова В. А. Введение в когнитивную лингвистику. М.: Флинта, 2007. 296 с.

46. Мерло-Понти М. Феноменологія сприйняття. Київ: Український Центр духовної культури, 2001. 552 с.

47. Морозова А. К. Проблема значения в свете современных семантических теорий. Вісник ХНУ. 2004. № 635. C. 114-117.

48. Попова 3. Д., Стернин И. А. Когнитивная лигвистика. М.: АСТ, Восток-Запад, 2007. 315 с.

49. Потапенко С. І. Орієнтаційна семантика: дискурсивне втілення. Вісник Львівського університету. Вип. 52. 2011. C. 253-261.

50. Селиванова Е. А. Процессы неологизации в ракурсе динамики этносознания. Лексико-грамматические инновации в современных восточнославянских языках. Днепропетровск: Пороги, 2007. С. 57-60.

51. Степанов Ю. С. В трёхмерном пространстве языка: Семиотические проблемы лингвистики, философии, искусства. М.: Наука, 1986. 336 с.

52. Хайдеггер М. Язык. М.: Фолио, 2003. 374 с.

53. Шепель Ю. А. Міжгалузева термінологічна омонімія у сучасній англійській мові. Дніпродзержинськ : ДДТУ, 2010. $335 \mathrm{c}$.

54. Шпет Г. Явление и смысл (Феноменология как основная наука и ее проблемы). М.: Наука, 2001. 219 с.

\section{REFERENCES}

1. Bell D. Social Framework of the Information Society. Oxford : Oxford U. Press, 1987. 315 p.

2. Davis E. Techgnosis: Myth, Magic and Mysticism in the Age of Information. NY : New York Publishers, Inc., 2001. $377 \mathrm{p}$.

3. Dobson H., Kürschne B. An Introduction to Responsible Technology. Retrieved from: https://tech2impact.com/anintroduction-to-responsible-technology/. 2021.

4. Fillmore, C. J. Frames Approach to Semantic Analysis. In B. Heine, \& H. Narrod (Eds.), The Oxford Handbook of Linguistic Analysis, 2010, pp. 313-340.

5. Gelernter D. Virtual Realism. Oxford : Oxford University Press, 1998. 138 p.

6. Hamilton G. Virtual reality. Business Week.1993, Issue 3, pp. 12-22.

7. Hausser R. Foundations of Computational Linguistics. Springer : Verlag Berlin Heidelberg, 1999. 534 p.

8. Heeter C. Implications of new interactive technologies for conceptualizing communication. Media use in the information age. Hillsdale, NJ: Erlbaum, 1989, pp. 85-108.

9. Heim M. Virtual Reality: Practice and Promice. LA : Wesport Publishers, 1994. 233 p.

10. James L. Exploring what "responsible technology" means. Retrieved from: https://medium.com/doteveryone/ exploring-what-responsible-technology-means-4f2a69b50a61. 2020.

11. Johnson F. Shall I Compare Thee to a Swarm of Insects? Searching for the Essence of the World Wide Web. The New York Times. 2003. pp. 10-12.

12. Knight S. Making authentic cultural and linguistic connections. Hispania. 1994, Vol. 77, pp 289-294.

13. Lakoff G. Women, fire and dangerous things. Chicago : CUP, 1987. 614 p.

14. Langacker R. W. Cognitive Grammar. The Oxford Handbook of Cognitive Linguistics. Oxford : Oxford Univ. Press, 2007, pp. 421-462.

15. Langacker R. W. Concept, Image, and Symbol: The Cognitive Basis of Grammar. Berlin \& New York: Mouton de Gruyter, 1991. 395 p.

16. Makhachashvili R., Models and Digital Diagnostics Tools for the Innovative Polylingual Logosphere of Computer Being Dynamics. Italian-Ukrainian Contrastive Studies: Linguistics, Literature, Translation. Monograph. Peter Lang GmbH Internationaler Verlag der Wissenschaften, Berlin, 2020. pp. 99-124.

17. Makhachashvili R., Semenist I. ICT Thesaurus Modelling Recommendations (based on innovations of European and Oriental languages). Studia Filologiczne, 7, 2020, pp. 117-128.

18. Minsky, M. A Framework for Representing Knowledge. In Frame Conceptions and Text Understanding, 1979, pp. 1-25. 
19. Monnin A. Humanity and Digital Characters in Virtual Worlds: Crossing the Fictional Boundaries. Posthumanity : Merger and Embodiment. Oxford, UK : Inter-Disciplinary Press, 2010, pp. 126-131.

20. Nyce J. M. From Memex to Hypertext. NY: Kahn Publications, 1994. 472 p.

21. Searle J. Minds, Brains, and Science. Oxford : Oxford U. Press, 1984. 142 p.

22. Suler J. Human Becomes Electric. From Books To Cyberspace Identities. NC : NCU Press, 2009, pp. 21-25.

23. Zhabotynska, S. Lexical Fields and Non-Lineal Dynamics of Cognitive Structures. Visnyk of the Lviv University. Series Philology, 2011, 52, pp. 3-11.

24. Zahavi D. Husserl's Phenomenology. Palo Alto : Stanford University Press, 2003. 312 p.

25. Andreeva I. V. Tsennostnaya kartina mira kak lingvisticheskaya i filosofskaya kategoriya. [Axiologial worldview as linguisitic an philosophical category]. Culture Analitics, 2006, \#3, pp. 14-21. [In Russian].

26. Andreychuk N. I. Semiotika lingvokulturnogo prostoru Angliyi kintsia XV - pochatku XVII stolittya. [Semiotics of linguocultural space of England in the late XVth early XVII centuries]. Lviv: Lviv Polytechnic Press, 2011. 277 p. [In Ukrainian].

27. Babushkin V. U. Fenomenologicheskaya filosofiya nauki - kriticheskiy analiz. [Phenomenological philosophy of science - critical review] M. : Academia, 1985. 246 p. [In Russian].

28. Baksanskiy O. E., Kucher E. N. Kognitivnoe reprezentirovanie kak mehanizm virtualizatsii realnosti. [Cognitive representation as a mechanism of virtual reality]. Virtualistics: existential and epistemological aspects. M.: Progress-Tradition, 2004. pp. 262-285. [In Russian].

29. Barthes R. Izbrannyie rabotyi: Semiotika: Poetika. [Selected readings on semiotics: Petics]. M. : Progress, 1989. 616 p. [In Russian]

30. Bakhtin M. M. Estetika slovesnogo tvorchestva. [Aethetics of verbal art]. M. : Art, 1979. 424 p. [In Russian].

31. Borchikov S. A. Metafizika virtualnosti. [The metaphysics of virtuality]. Proceeding of virtualistics laboratory. 2000. Issue. 8. pp. 29-33. [In Russian].

32. Budko V. V. Adekvatnost nauchnogo poznaniya. [The adequacy of scientific inquiry]. Kharkiv: Logos, 1990.154 p. [In Russian]

33. Husserl E. Kartezianskie razmyishleniya. [Cartesian musings] SPb.: Academia, 2001. 516 p. [In Russian].

34. Devterev I. V. Filosofskiy analiz fenomena interaktivnoy nauchnoy deyatelnosti v INTERNET (fenomenologicheskiy, evristicheskiy i pragmaticheskiy aspektyi). [Philosophical analysis of the phenomenon of interactive scientific activity in the INTERNET (phenomenological, heuristic and pragmatic aspects)] K., 2000.188 p. [In Russian].

35. Ienikieieva S. M. Systema slovotvoru suchasnoi anhliiskoi movy: synerhetychnyi aspekt (na materiali novoutvoren kintsia XX - pochatku XXI stolit). [Word-building system of the modern English: based on the innovations of the late XX early XXI century] K., 2011. 438 p. [In Ukrainian].

36. Ingarden R. Vvedenie v fenomenologiyu Edmunda Gusserlya. [Introduction to Edmund Husserl's phenomenology]. M. : Intellectual book house, 1999. 267 p. [In Russian].

37. Kamsha V. P., Kamsha L. S., Kamsha Yu. V. Pro kibernetyku druhoho etapu NTR. [On cybernetics of the $2^{\text {nd }}$ stage of STR]. Complex systems and processes. 2010. 1 (17). pp. 25-41. [In Russian].

38. Karasik V. I. Yazyikovoy krug: lichnost, kontseptyi, diskurs. [Language circle: personality, context, discourse]. Volgograd: Peremena, 2002. 477p. [In Russian].

39. Kutyirev V. A. Kultura i tehnologiya: borba mirov. [Culture and technology: the clash of the worlds] M., ProgressTradition, 2001. $336 \mathrm{p}$.

40. Losev A. F. Vesch $\mathrm{i}$ imya. [The thing and the name]. Existence. Name. Cosmos. M.: Myisl, 1993. p. 805 - 872.

41. Mamardashvili M. K., Pyatigorskiy A. M. Simvol i soznanie. [Symbol and consciousness]. Metaphysical musings on consciousness, symbolism and language. M. : Shkola, 1997. 216 s. [In Russian]

42. Mamardashvili M. K. Kak ya ponimayu filosofiyu. [How I understand philosophy]. Selected papers, documents and talks. M.: Progress, 1999. 415 p. [In Russian].

43. Martinyuk A. P. Konstruyuvannya genderu v anglomovnomu diskursi. [Construction of gender in the English discourse]. Kharkiv : Constanta, 2004. 292 p. [In Ukrainian].

44. Martyniuk S. S. Metafizychni vymiry liudskoho buttia. [Metaphysical dimentionas of the human existence]. Zaporizhzhia : ZSU Press, 2001. 198 p. [In Ukrainian].

45. Maslova V. A. Vvedenie v kognitivnuyu lingvistiku. [Introduction to cognitive linguistics]. M. : Flinta, 2007.296 p. [In Russian].

46. Merlo-Ponty M. Fenomenolohiia spryiniattia. [Phenomenology of preception]. Kyiv : Ukrainian ceter for spiritual culture, 2001. 552 p. [In Ukrainian].

47. Morozova A. K. Problema znachenyia v svete sovremennykh semantycheskykh teoryi. [The issue of meaning in veiew of modern semantic theories]. KhNU Boulletin. 2004, No 635, pp. 114-117. [In Russian].

48. Popova Z. D., Sternin I. A. Kognitivnaya ligvistika. [Cognitive linguistics]. M. : AST, East-West, 2007.315 p. [In Russian].

49. Potapenko S. I. Oriientatsiina semantyka: dyskursyvne vtilennia. [Orientational semantics]. Lviv University Boulletin. No. 52. 2011. p. 253-261. [In Russian].

50. Selivanova E. A. Processy` neologizacii v rakurse dinamiki e`tnosoznaniya. Leksiko-grammaticheskie innovacii v sovremenny`x vostochnoslavyanskix yazy`kax. [Neologization processes through the lens of ethnic consciousness dynamics]. Dnepropetrovsk: Porogi, 2007. pp. 57-60. [In Russian]. 
51. Stepanov Yu. S. V tryoxmernom prostranstve yazy'ka: Semioticheskie problemy` lingvistiki, filosofii, iskusstva. [In the 3D space of the language: Semiotic issues of linguistics, philosophy and art]. M.: Academia, 1986.336 p. [In Russian]. 52. Heidegger M. Yazy`k. [Language]. M.: Folio, 2003. 374 p. [In Russian].

53. Shepel Yu. A. Mizhhaluzeva terminolohichna omonimiia u suchasnii anhliiskii movi. [Cross-sectorial terminological homonymi in the modern English]. Dniprodzerzhynsk : DDTU, 2010. 335 p. [In Ukrainian].

54. Shpet G. Yavlenie i smy'sl (Fenomenologiya kak osnovnaya nauka i ee problemy'). [Phenomenon and Sense (Phenomenology as a core science and its issues]. M.: Academia, 2001. 219 p. [In Russian]. 